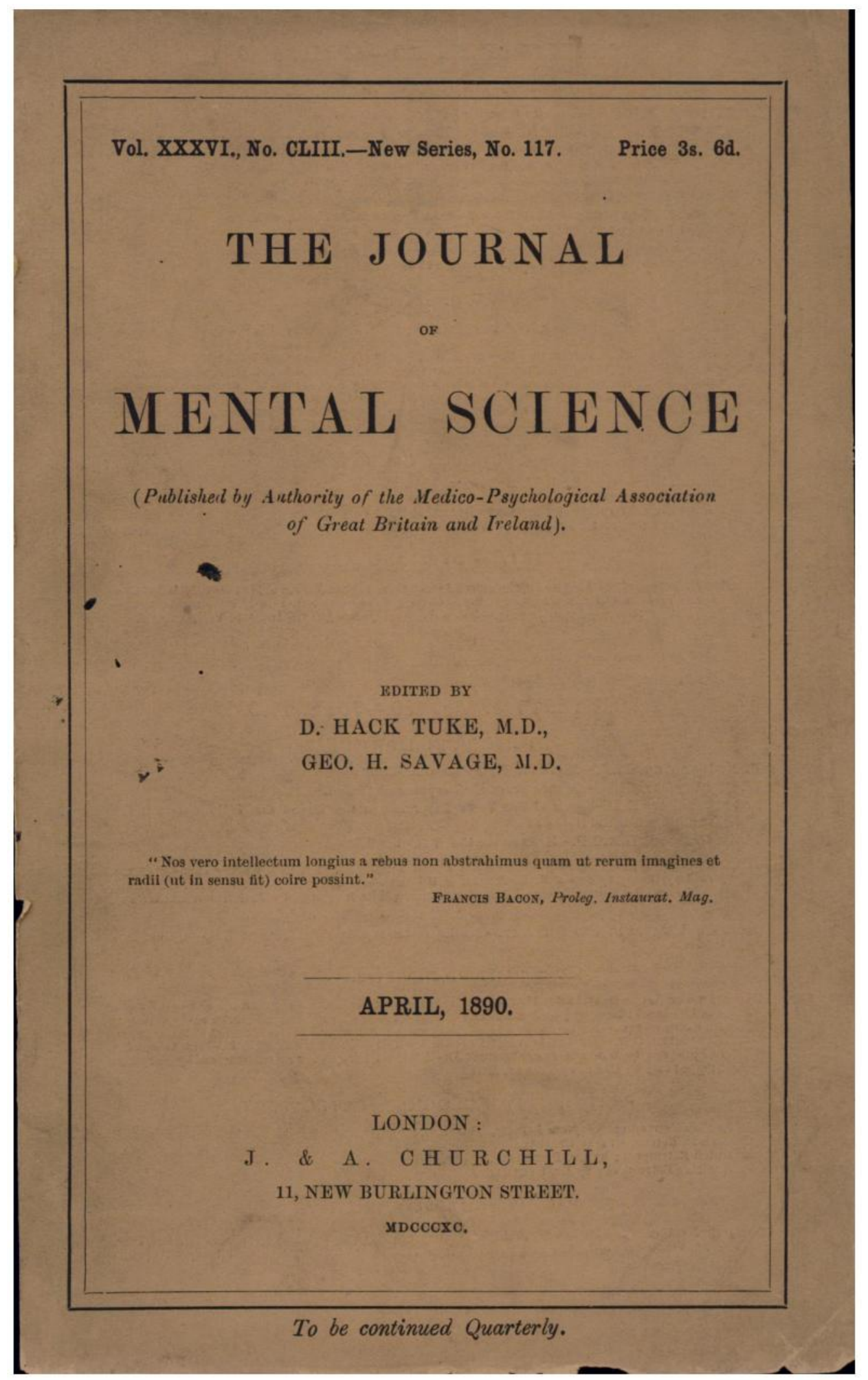


CONTENTS OF No. 149.-APRIL, 1889.

PART I.-ORIGINAL ARTICLES.

C. T. Dent. F.R.C.S.-Insanity following Surgical Operations.

Rev. W. D. Morrison. - Reflections on the Theories of Criminality.

Franc1s Warner, F.R.O.P.-Muscular Movements in Man, and their Evolution in the Infant ; A Study of Movement in Man, and its Evolution, together with Inferences as to the Propertics of Nerve-Centres and their Iodes of Action in Expressing Thought.

Clinical Notes and Cases. - Cases of Incendiarism with Commentary ; by Jour BAKKa, M. B.Case of Folie in Deux ; by M. J. NoLAs. - On a Case of Acute Mania, with Symmetrical Gangrene Case of Folie in Denx; by M. J. NoLAs. - On a Case of Acute
of the Toes (Raynuad's Discase); by J. MAcrakrsos, M.B.

Occasional Notes of the Quarter.-Lunacy Aets Amendment Bill.-County Councils and Pensions, - The Suicide of Rudolph, Cronn Prince of Austria.

\section{PART 11.-REVIEWS.}

Nental Evolution in Man-Origin of Human Faculty ; by G. J. Bosaxes, LL.D.-Om Hypnotismens

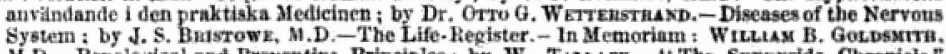
M.D.-Penological and Preventive Prineiples; by W. TALlACK.- "The Sunnyside Chronicle" and the "St. Andrew's Review."-On the Treatment by Suspension of Locomotor Ataxy and some other Bpinal Affections, as deseribed by Professor Chareot; translated by $\mathbf{A}$. de Watrsvil.LE, M.D. - VIayne's M edical Vocnbolary, being an Explanation of all terms and Phrases used i the Various Departments of Medieal Beienee and Praetice ; by W. W. WAGatayre, F.R.C.S.

PART III.-PSYCHOLOGICAL RETROSPECT

l. French Retrospeet. By T. W. MoDowall, M.D.

2. Dutch Retrospect. By J. PiETk hsses, M.D.

3. American Retrospect. By Flitcurar Besch, M.D.

4. Colonia! Retrospect. By D. HAcx TUEE, M.D.

PART IV.-NOTES AND NEWS.

Quarteriy Meeting of the Medico-Psychological Association, held at York, on Thursiay, 14th March,Legal Tests and Criminal Responsibility,-Correspondence, - Obituary.-M.P.C Examinations.-
Asylum Etatistics,-Appointments, - Index Medico-Psychologicus,-Index to Vol. xxxiv, do.

\section{CONTENTS OF No. 150.-JULY, 1889.}

\section{PART I.-ORIGINAL ARTICLES.}

F. N. Manning, M.D.-Address in Psychological Medielne.

W. S. Playfair, M.D.-On the Cure of the Sorphia and Alcoholic Habit.

Robert Baker, M.D.-Notes of Ten Years' Experience in the Use of the Turkish Bath in the Treatment of Mental IIl-health.

W. R. Watson, L.R.C.P.-Notes on the Use of Sulphonal.

Clinical Notes and Cases.-Case of Attempted Suicide; by Dr. Ungunarr.-Tumour of the Pituitary Body; by JaMss B. Warrwzt., M.B-Cases of Insanity with Interesting Pathological Conditions; by Jazrs Rokre, M.D.- Hyzedema and its Insanity ; by J. Comusc Mackeszie, M.B.

Occasional Notes of the Quarter.-Pensions,-Lunacy Acts Amendment Bill.-Asylum Attendants.

PART II,-REVIEWS.

Hypnotisme en Suggestie en hunne Therapeutisehe beteekenis ; by Dr. B. H. Srepuas, -Franeis Bacon: His Life and Thilosophy; by Jous NichoL, N. A. - The insane in Foreign Countries ; by Wrisust P. LETCHWontH. - Nature and Man : Essays Schntifle and Philosophical ; by Wrutas B. of Epint of Epilepsy; by WrLIAS ALExasDen, M.D.- Psycho-Therapentics : or Treatment by Sleep and

\section{PART III.-PSYCHOLOGICAL RETROSPECT.}

1. English Retrospect.- Asylum Reports, 1889 (for 1888).

2. German Retrospect; by Dr. IniLAsD.

3. Dutch Retrospect; by Dr, PIETEitses.

4. Austrian Retrospect; by Dr. Urq бнант.

\section{PART IV.-NOTES AND NEWS.}

Quarterly Meeting of the Medico-Psychological Association, held at Bethlem Honyitul, June 6th, 1889. -Dr. Yellowless on the Use of Restraint in the Treatment of the Insane,-Obituary,-Appoint. 


\section{The Journal of Mental Science.}

Original Papers, Correspondence, \&c., to be sent direct to Dr. Hacr Turx, Lyndon Lodge, Hanwell, W. (Town address, 63, Welbeck Street, W.)

English books for review, pamphlets, exchange journals, \&c., to be sent by book-post to the care of the publishers of the Journal, Messrs. J. and A. Churchill, New Burlington Street.

Authors of Original Papers (including "Cases") receive 25 reprints of their articles. Should they wish for additional Reprints they can have them on application to the Printers of the Journal, South Counties Press Limited, Lewes, at a fixed charge.

The copies of The Journal of Mental Science are regularly sent by Book-post (prepaid) to the Ordinary and Honorary Members of the Association, and the Editors will be glad to be informed of any irregularity in their receipt or overcharge in the Postage.

The following are the EXCHANGE JOURNALS :-

Zeitschrift für Psychiatrie; Archiv für Psychiatrie und Nervenkrankheiten; Centralblatt für Nervenheilkunde, Psychiatrie, und gerichtliche Psychopatholngie; Der Irrenfreund; Neurologisches Centralblatt; Revue des Sciences Médicales en France et à l'Étranger'; Annales Médico-Psychologiques ; Archires de Neurologie; Le Progrès Médical; Revue Philosophique de la France et de l'Étranger, dirigée par Th. Ribot; Revue. Scientifique de la France et de l'Etranger; Nouvelle Iconagraphie de la Salpêtriere; Bulletin de la Société de Médecine Mentale de Belgique; Russian Archives of Psychiatry and Neurology; Archivio Italiano per le Nalattie Nervose e per le Alienazioni Mentali; Archivio di psichiatria, scienze penali ed antropologia criminale : Direttori, Lombroso et Garofalo; Rivista Clinica di Bologna, diretta dal Professore Luigi Concato e redatta dal Dottore Ercole Galvani; Kivista Sperimentale di Freniatria e di Medicina Legale, diretta dal Dr. A. Tamburini; Archives Ital. de Biologie; Psychiatrische Bladen; The American Journal of Insanity; The Journal of Niervous and Mental Disease; The Quarterly Journal of Inebriety, Hartford, Conn.; The Alienist and Neurologist, St. Lonis, Misso.; Medico-Legal Journal; The American Journal of the Medical Sciences; The Dublin Journal of Medical Science; The Edinburgh Medical Journal; The Lancet; The Practitioner; The Journal of Physiology; The Journal of the Anthropological Society; The British Medical Journal; The London Medical Recorder; The Asclepiad; Reports of the Psychical Research Society; Brain; Mind; Polybiblion; The Index Medicus ; Revista Argentina; Revue de l'Hypnotisme; Bulletins de la Société de Psychologie Physiologique; Journal de Médicine de Bordeaux; The Hospital; The American Journal of Psychology; The Journal of Public Health. 
Vol. XXXVI., No. 153. (New Series, No. 117.)

THE JOURNAL OF MENTAL SCIENCE, APRIL, 1880.

[Published by authority of the Medico-Psychological Association of Great Britain and Ireland.]

\section{CONTENTS.}

PART I.-ORIGINAL ARTICLES.

James Ross, M.D. - On the Psychical Disorders of Peripheral Neuritis.

A. R. Orquhart, M.D.-Description of the New Hospital Wings at James Murray's Royal Asylum, Perth. 172

Robert Jones, M.D. - The Mouth in Backward Children (Imbecile) of the Mongolian Type

R. Percy Smith, M.D., and A. T. Myers, M.D.-On the Treatment of Insanity by Hypnotism

Clinical Notes and Cases.-The Morbid Histology of a Case of Syphilitic Epileptic Idiocy; by F. ST. John Bullen. With Plate.-Cerebral Tumour involving the Frontal Lobes; by A. HiLL GRIFFiTH, M.D., and T. Stefie Sheldon, M.B.-Case of Peripheral (Alcoholic) Neuritis ; by Dr. McDowall and J. C. Fenwick. (Plate) . . 213-231

Occasional Notes of the Quarter.-Proposed Hospital for the Insane in London.-Alleged Increase of Insanity.--Retreats under the Inebriates Act

$$
\text { PART II.-REVIEWS. }
$$

A Text Book of Mental Diseases, with special reference to the Pathological Aspects of Insanity; by W. Bevan LEWIs, M.R.C.S.-The Rheumatic Diseases (so-called), with original suggestions for more clearly defining them; by Hugh Lane, M.D., and Charles T. Griffiths, M.D.Civilization and Progress; by John Beatrie Crozier.- Etudes Cliniques sur les Maladies Mentales et Nerveuses; par le Docteur JuLES FaLreT.-Synopsis of Human Anatomy; by JAMES K. Young, M.D.The Philosophy of Mysticism; by CARL Du PreL.-Old Age : by George MURRAY HumpirReY,. M.1..-An Experimental Study in the Domain of Hypnotism; by Dr. R. von KRAFFT-Ering.-Die Rolle der Suggestion bei gewissen Erscheinungen der Hysterie und des Hypnotismus, Kritisches und Experimentelles; von Dr. Armand HuECKEL.-Lectures on Nervous Diseases; by Ambrose L. Rannex, M.D.-A German-English Dictionary of Medical Terms; by Frederick Treves, F.R.C.S., and Hugo Long, B.A.-The Contemporary Science Series; by Havelock Ellis.-The Asclepiad; by BenJamin Ward Richardson, M.D.- Recherches sur l'Etiologie de la Paralysie Générale chez l'Homme; par le Dr. Jules Christian . . . 242-267

$$
\text { PART III.-PSYCHOLOGICAL RETROSPECT }
$$

1. French Retrospect; by HAVELOCK ELLIS, L.S.A. . . . 267

2. Australian Retrospect; by D. HACK TUKE, M.D. $\quad \cdot \quad \cdot \quad \cdot 276$

3. German Retrospect; by W. W. IRELAN D, M.D. $\quad . \quad$. $\quad .278$

4. Russian Retrospect; by Robert Jones, M.D. _ . . . 288 PART IV. - NOTES AND NEWS.

Quarterly Meeting of the Medico-Psychological Association, held at Manchester, March 13th.-Lunacy Consolidation Bill.-Coroner's Censure of a Surgeon.- The Royal Edinburgh Asylum for the Insane.-Changes in the Irish Lunacy Board.- Tenth International Medical Congress, Berlin, 1890.-Invitation to the International Medico-Scientific Exhibition, Berlin, August, 1890.-Proposed Hospital for the Insane in London.-Certificate of Efficiency in Psychological Medicine. M.P.C. Examination.-Index Medico-Psychologicus.-Appointments, \&c. 299-316 